I. Trunova, Cand. Sc. (Tech.), Assoc. Prof., orcid.org/0000-0001-7510-4291, O. Miroshnyk, Dr. Sc. (Tech.), Prof., orcid.org/0000-0001-8745-9903,

O. Savchenko, Cand. Sc. (Tech.), Assoc. Prof., orcid.org/0000-0002-6401-0852,

O. Moroz, Dr. Sc. (Tech.), Prof., orcid.org/0000-0002-8520-9211
Kharkiv Petro Vasylenko National Technical University of Agriculture, Kharkiv, Ukraine, e-mail: omiroshnyk@ukr.net

\title{
THE PERFECTION OF MOTIVATIONAL MODEL FOR IMPROVEMENT OF POWER SUPPLY QUALITY WITH USING THE ONE-WAY ANALYSIS OF VARIANCE
}

Purpose. Perfection of motivational mathematical model for improvement of power supply quality with using of the one-way Analysis of Variance for realization in system of automated management of the regulated company for power distribution.

Methodology. A one-way Analysis of Variance of the SAIDI data of reports of subdivisions of the regulated company for power distribution for estimation of the importance of influence of these subdivisions on power supply continuity is applied.

Findings. We have the generalized and adjusted ratios, which allow determining the factor of stimulation of achievement of the best results of activity on power supply continuousness with subdivisions of the regulated company for power distribution. The incentive scheme for improving these subdivisions for power distribution is improved. Key indicators of power supply quality for annual estimation of results of activity of subdivisions of regulated companies for power transfer and power supply are determined.

Originality. A motivational mathematical model of amelioration of power supply quality by generalization and accurate definition of formulas for calculation of the factor of stimulation of achievement of the best results of activity of subdivisions of the regulated company is improved.

Practical value. The improvement of the motivational model of amelioration of power supply quality will allow using it more effectively in the automated management system of the regulated company for power distribution.

Keywords: one-way variance analysis, motivational mathematical model, power supply quality

Introduction. The implementation of an incentive scheme for maintaining or improving general continuity levels was one of recommendations of the Council of European Electricity Regulators (CEER) that were submitted in $5^{\text {th }}$ benchmarking report [1] in 2011.

Many European countries already have systems for regulating the quality of power supply, which are based on the interaction of three process participants: Regulator, Regulated Company (RC) and Power Consumers.

As noted in the 6th benchmarking report CEER about the quality of power and gas supply [2] systems for regulating the power supply quality function based on:

- fixation of power supply continuity;

- maintenance and increase in the overall levels of power supply continuity through investment decisions;

- compensation to Consumers for discrepancy of guaranteed minimum quality standards for power supply.

Also the review of use of incentives systems for the RC in the European countries on the basis of key reliability metrics is considered in [2].

Key reliability metrics are indicated in IEEE Std. 1366 Trial-Use Guide for Electric Power Distribution Reliability Indices. First of all, this is a System Average Interruption Duration Index (SAIDI).

A motivational model for RC distribution subdivisions is also needed to improve the quality of power supply. It should take into account the possible impact of the unit on the continuity of power supply, due to systemic shortcomings of the distribution networks maintenance. It should also take into account other key metrics of service quality - voltage quality (VQ) and commercial quality.

Literature review. As noted in [3] a system of quality management of power supply is implemented in Ukraine, using the experience of many countries of the world.

Under the Law of Ukraine "On the market of electric energy" [4] Regulator - the National Commission which is car-

(C) Trunova I., Miroshnyk O., Savchenko O., Moroz O., 2019 rying out state Regulation in spheres of Power and Municipal Services (NCRPMS), defines the parameters of power supply quality with regard to a level of power supply continuity, of commercial quality of services on transfer, distribution and power supply, and also of VQ.

Regulator approves their rate; defines the order and the rate of compensation to Consumers for discrepancy of guaranteed minimum quality standards for power supply.

The procedure of compensation to Consumers through discrepancy of the guaranteed standards of the commercial quality has been in effect since 2016 according to NCRPMS Resolution No. 1841 dated August 10, 2016. Today this procedure is further developed by the Resolution of the NCRPMS No. 375 dated June 12, 2018 [5]. This motivates the general RC on the transmission, distribution and supply of power to improve the service quality.

Regulator introduces Rate Asset Base Tariff Regulation (RAB) in Ukraine. The RAB provides motivation of achievement of target parameters of continuous supply of qualitative electric energy. These components have technical aspects. Continuous supply and VQ depend on maintenance quality of distributive networks equipment first of all.

As investigated by L. Bertling, R. Allan, and R. Eriksson in [6], the service quality of power equipment for power supply systems has a direct impact on the reliability indices of power supply. The VQ depends to a large extent on the technical state of distribution networks as well.

Recommendations on the methodology for evaluating the results of work of divisions and individual specialists of the RC to motivate the improvement of a power supply quality using easy algorithms in an accessible interface, for example, in Microsoft Excel spreadsheets, or using automated control systems, were provided at the 3rd International IEEE Conference From Intellectual Power and Power Systems by Miroshnyk O. O., Savchenko O. A. and Trunova I. M. [7].

Unsolved aspects of the problem. The incentive schemes for improving power supply quality based on one-way Analysis of Variance (ANOVA) of database of SAIDI values from subdivi- 
sions of RC [3, 7] need improvement and development in the direction of expanding the list of key indicators for the annual evaluation of the specialists' activity results in RC subdivisions not only for distribution, but also for the transmission and supply of power, taking into account the provisions and requirements of the latest normative documents, in particular, Regulation No. 374 dated December 12, 2018 [8]. It is also necessary to generalize and clarify the formulas of motivational mathematical model for improvement of power supply quality provided by acceptance of a hypothesis that subdivision of $\mathrm{RC}$ is the influencing factor on the SAIDI.

Purpose. The purpose of the work is to generalize and clarify the formulas of motivational mathematical model for improvement of a power supply quality provided by acceptance of a hypothesis that subdivision of RC is the factor influencing the SAIDI.

It is to determine the list of key indicators for the annual evaluation of the specialist's activity results in subdivisions of $\mathrm{RC}$ for distribution, transmission and supply of power. It will contribute to the achievement of the strategic goal as improvement of a quality of power supply.

Results. According to [8], quarterly, Ukraine's RC reports to NCRPMS according to No. 11-NCRPMS form about the main indices of power supply continuity (SAIDI - System Average Interruption Duration Index, SAIFI - System Average Interruption Frequency Index, ENS - Energy Not Supplied, etc.), reports by No. 12-NCRPMS-distribution form and No. 12-NCRPMS-supply form (about commercial quality).

Annually, the RC reports to NCRPMS by No. 12-NCRPMS-transmission form ("Report on indices of commercial service quality of power transmission"), No. 13-NCRPMS form "Report on reliability (continuity) indices of power transmission" and No.14-NCRPMS form ("Report on elimination of the reasons for unsatisfactory voltage quality for complaints of consumers").

Each $\mathrm{RC}$ has subdivisions $\mathrm{RC}_{1}, \mathrm{RC}_{2}, \mathrm{RC}_{3}, \ldots, \mathrm{RC}_{n}$, that provide their reporting data, and then form general reporting to the Regulator for the above reporting forms.

If to consider, for example, $\mathrm{RC}$ for power distribution (it is Distribution System Operator), then the reports of RC territorial subdivisions $\left(\mathrm{RC}_{1}, \mathrm{RC}_{2}, \mathrm{RC}_{3}, \ldots, \mathrm{RC}_{n}\right)$ allow analyzing the database of service quality indices: data on performance of guaranteed standards of service quality; reliability (continuity) indices SAIDI, SAIFI, ENS, etc.

In order to identify the disadvantages of maintenance of distribution networks, the analysis of SAIDI database enables to appreciate the quickness of elimination of the equipment failure, first of all. It is influenced by qualification and quantity of the repair personnel, provision of spare parts and consumables, etc.

The analysis of the SAIFI database enables to appreciate the quality of previous service (quality of the analysis of technical condition of distributive networks, timeliness and completeness of maintenance, repair, rehabilitation, modernizations of distributive networks, etc.).

The database analysis of other indicators, for example, ENS allows us to assess, in particular, how well the power supply system is designed in terms of the reliability for the most powerful consumers.

However, first of all, analysis of data for each of the RC subdivisions should identify whether RC subdivisions are influencing factors for this indices or not in order to create an effective incentive scheme for improving the service quality.

For example, if $\mathrm{RC}$ subdivisions are not factors influencing the SAIDI, then analysis allows determining RC subdivisions with the largest or least SAIDI values, it does not depend on the quality of maintenance of distribution networks by these subdivisions. In this case the largest SAIDI values are caused by influence, for example, abnormal weather conditions, etc.

If RC subdivisions are factors influencing the SAIDI, then the RC(-s) with the largest SAIDI values is (are) subdivision (-s) with poor quality of maintenance of distributive networks (as the major factor of influence on power supply continuity) and systemic shortcomings in the work. In this case, further in-depth analysis of the reasons for this is necessary to develop measures to improve the service quality and, accordingly, the reliability of power supply. At the same time, it is desirable to use available computer analysis tools, such as the one-way Analysis of Variance from the Microsoft Excel Analysis Package.

The ANOVA is a method of mathematical statistics that allows one to find the significance of differences in mean values in the database. Unlike t-test, the ANOVA allows comparing the mean values of more than two groups of data. According to David M. Diez, Christopher D. Barr, Mine CetinkayaRundel [9] the ANOVA is suited to a wide range of practical problems. It is conceptually similar to multiple two-sample ttests, but results in less type I error.

Analysis of the possibility of using the ANOVA from the Microsoft Excel Analysis Package to identify the RC subdivisions for power distribution, which has systemic shortcomings of the distribution networks maintenance has been done in [7]. The factor in the ANOVA is an independent variable that should be categorical. The independent variable is RC subdivisions $-\mathrm{RC}_{n}(n=1, \ldots m ; m=8$ in this example $)$. Influence of factor $\mathrm{RC}_{n}$ on a dependent metric variable is investigated.

The reasons of breaks in power supply of consumers are quarterly analyzed according to the recommendations of regulatory service documents (for example, the standard 40.1.20.576:2005 [10]). Among them there can be defects of installation, defects of repair, changing properties of materials, untimely carrying out of service, etc. At the same time, a database of the reasons of breaks in power supply of consumers is created as well. A conclusion about which $\mathrm{RC}_{n}$ has systemic shortcomings of the networks service can be made on database of several reports. However, the authenticity of these data is significantly influenced by the subjective factor (qualification of staff, which evaluates the reasons for breaks in power supply, honesty, etc.).

In [7] it is proposed to use the reliability indices (SAIDI and (or) SAIFI) to determine the significance of the influence of a RC subdivision on the continuity of power supply. These indices can be fixed and calculated automatically, creating a database for reporting of power energy distribution RC (No.11NCRPMS form) and for its using in one-way ANOVA.

Since currently the Regulator sets target indices for SAIDI for the continuity of power supply, the example with dependent variable of the SAIDI was considered.

The target indices for the SAIDI are calculated based on actual SAIDI values for three years. So, it is possible to recommend the use of the one-way ANOVA for analysis of quarterly RC subdivisions' report database in the past three years.

However, in [7] a conditional example was considered with SAIDI database out of quarterly RC subdivisions' reports for one year; the results of the one-way ANOVA for quarterly SAIDI data of eight RC subdivisions are cited in Tables 1 and 2.

This is an example with acceptance of hypothesis that an $\mathrm{RC}$ subdivision is the factor influencing the SAIDI.

Also, the results of one-way ANOVA showed that the difference in the data is significant (Tables 1,2). Such a conclusion was made, since the probability of taking the null hypothesis is small (P-value is 0.0037 , which is less than the significance level) and according to check of Fisher's statistics of testifies: $F>F_{\text {crit }}(4.22>2.42)$.

The result is significant if $F>F_{\text {crit }}$, since this indicates a significant difference between the mean values in groups.

Accordingly, it is the opportunity to draw a conclusion that in RC subdivisions with the greatest average SAIDI value for a year, there is a poor quality of maintenance of distributive networks (as the major factor of influence on power supply continuity) and systemic shortcomings in the work.

Monitoring and expansionary action of achievement of the best results of activity of companies divisions and workers for improvement of power supply quality is used. 
One-way Anova (summary)

\begin{tabular}{|l|c|c|c|c|}
\hline \multicolumn{5}{|c|}{ SUMMARY } \\
\hline \multicolumn{1}{|c|}{ Groups } & Count & Sum & Average & Variance \\
\hline Rows 1 & 4 & 930 & 232 & 10653 \\
\hline Rows 2 & 4 & 1261 & 315 & 16679 \\
\hline Rows 3 & 4 & 1059 & 265 & 5048 \\
\hline Rows 4 & 4 & 1886 & 472 & 29584 \\
\hline Rows 5 & 4 & 940 & 235 & 16888 \\
\hline Rows 6 & 4 & 333 & 83 & 8140 \\
\hline Rows 7 & 4 & 1508 & 377 & 6669 \\
\hline Rows 8 & 4 & 730 & 182 & 14077 \\
\hline
\end{tabular}

Table 2

Analysis of variance

\begin{tabular}{|l|c|c|c|}
\hline $\begin{array}{c}\text { Source of } \\
\text { Variance }\end{array}$ & $\begin{array}{c}\text { Between } \\
\text { Groups }\end{array}$ & $\begin{array}{c}\text { Within } \\
\text { Groups }\end{array}$ & Total \\
\hline SS & 397446 & 323213 & 720659 \\
\hline df & 7 & 24 & 31 \\
\hline MS & 56778 & 13467 & - \\
\hline F & 4.22 & - & - \\
\hline P-value & 0.0037 & - & - \\
\hline F crit & 2.42 & - & - \\
\hline
\end{tabular}

This practice began to be introduced in the RC. For example, the Distribution System Operator of DTEK, Dnipro Power Networks applies Key Performance Indicators (KPI) for the annual evaluation of the results of the activity of the employees. It is an estimation system which helps distributive companies to achieve the strategic purposes (in particular, improvement of power supply quality).

Usually, the system of money incentives for employees on the basis of KPI is created. For example, annual bonus $(A B)$ for management of $\mathrm{PC}_{\mathrm{i}}$ can be defined by using the following formula

$$
A B_{i}=X_{i} \cdot B \cdot \sum_{j=1}^{k}\left(K P I_{j} \cdot P_{j}\right) / 100,
$$

where $B$ is the base official salary; $P_{j}$ is specific weight of the $j^{\text {th }}$ $\mathrm{KPI} ; X_{i}$ is the factor for $\mathrm{PC}_{i}$ which defines which part of the base official salary $B$ is used for calculation of annual bonus $A B$. It is the incentive factor for achieving the best performance of the RC subdivisions for the transmission, distribution or supply of power energy.

In the example, which was considered in [7], it was proposed in case of acceptance of the hypothesis that an RC subdivision is the factor influencing the SAIDI, to choose the coefficient $X_{i}$ according to rank of $\mathrm{PC}_{\mathrm{i}} r(r=1, \ldots, m)$ in the rating (in this case $X_{i}=X_{r}$ ).

The highest rating has $\mathrm{RC}_{\mathrm{i}}$ with the least average SAIDI. For the example, in question, $\mathrm{RS}_{6}$ has the highest rating (Table 3).

Such conditions in Table 3 for choice $X$ according to rank of $\mathrm{RC}_{i}$ in the rating are realized

$$
\left.\begin{array}{ll}
X_{r}=1, & r=1 \\
X_{r}=0, & r=m \\
X_{r}=\left(X_{r-1}-0.15\right), & r=(2, \ldots, m-1)
\end{array}\right\},
$$

where $X_{r}$ is the factor for $\mathrm{PC}_{i}$, which is determined by the rating of $\mathrm{PC}_{i}$.

The generalized conditions (2) in [7] are represented as
Determination of the coefficient $x_{i}$ by rating

\begin{tabular}{|l|c|c|c|}
\hline \multicolumn{1}{|c|}{$\mathrm{RC}_{i}$} & Rank of $\mathrm{RC}_{i}(\mathrm{r})$ & $\overline{\text { SAIDI }}$ & $\mathrm{X}_{\mathrm{r}}$ \\
\hline $\mathrm{RC}_{6}$ & 1 & 83 & 1.00 \\
\hline $\mathrm{RC}_{8}$ & 2 & 182 & 0.85 \\
\hline $\mathrm{RC}_{1}$ & 3 & 232 & 0.70 \\
\hline $\mathrm{RC}_{5}$ & 4 & 235 & 0.55 \\
\hline $\mathrm{RC}_{3}$ & 5 & 265 & 0.40 \\
\hline $\mathrm{RC}_{2}$ & 6 & 315 & 0.25 \\
\hline $\mathrm{RC}_{7}$ & 7 & 377 & 0.10 \\
\hline $\mathrm{RC}_{4}$ & 8 & 472 & 0.00 \\
\hline
\end{tabular}

$$
\begin{array}{ll}
X_{r}=1, & r=1 \\
X_{r}=0, & r=m \\
X_{r}=\left(X_{r-1}-Y\right), & r=(2, \ldots \\
Y=1 /(m-1) &
\end{array}
$$

where $Y$ is the step of reducing the share of the basic salary $B$ (it is used to calculate the annual premium).

However, the motivational model should also take into account possibility of applying penalties in the case where SAIDI values are significantly higher than normal. The norm is the target indicator, which is calculated and adjusted by the Regulator to each $\mathrm{RC}$ for distributing power energy annually.

In accordance, we offer condition (3) to present in such a generalized form

$$
\left.\begin{array}{ll}
X_{r}=L, & r=1 \\
X_{r}=K, & r=m \\
X_{r}=\left(X_{r-1}-Y\right), & r=(2, \ldots m-1) \\
Y=1 /(m-1) &
\end{array}\right\},
$$

where $L$ is the share of the basic salary B (it is used to calculate the maximum annual bonus); $K$ is the coefficient that determines the method of motivation to achieve better results of performance ( $K \geq 0$ - in the case where no penalties are applied; $K<0$ - in the case where penalties are applied).

At that, the limit, when it is necessary to apply penalties, can be determined in the RC, for example, on the basis of the marginal value of the excess of the average SAIDI.

Another approach is definition of factor $X_{i}$ proportionally to the SAIDI value. It is recommended in cases when it is impossible to accept a hypothesis about $\mathrm{PC}_{\mathrm{i}}$ as a factor influencing the SAIDI. If that is the case, then in [7] definition of factor $X$ (in this case $X_{i}=X_{p}$ ) is offered with realization of such conditions

$$
\begin{aligned}
& X_{1}=L, \quad S A I D I_{1}=S A I D I_{p \min } \\
& X_{p}=\left(X_{p-1}-\frac{S A I D I_{p}}{\sum_{p=1}^{m} S A I D I_{p}}\right), \quad p=(2, \ldots m)
\end{aligned},
$$

where $X_{p}$ is the factor for $\mathrm{PC}_{i}$, which is determined proportionally to the SAIDI.

The example of definition of factor $X_{i}$ proportionally to the SAIDI in Table 4 for $L=1$ is presented.

Analysis of the data in Tables 3 and 4 shows that with equal output data, the choice of factor $X i$ according to rank gives, as a result, lower values of the $X_{i}$ factor compared to the values that were calculated in proportion to the SAIDI. It happens even in the case where no penalties are applied $(K=0)$.

We also suggest using the average SAIDI as one of the key indicators of the performance of the management of the RC subdivision for the power distribution. 
Table 4

Definition of factor $x_{i}$ proportionally to the SAIDI

\begin{tabular}{|l|l|l|}
\hline $\mathrm{RC}_{i}$ & $\overline{\text { SAIDI }}_{p}$ & $\mathrm{Xp}$ \\
\hline $\mathrm{RC}_{6}$ & 83 & 1.00 \\
\hline $\mathrm{RC}_{8}$ & 182 & 0.92 \\
\hline $\mathrm{RC}_{1}$ & 232 & 0.81 \\
\hline $\mathrm{RC}_{5}$ & 235 & 0.70 \\
\hline $\mathrm{RC}_{3}$ & 265 & 0.58 \\
\hline $\mathrm{RC}_{2}$ & 315 & 0.43 \\
\hline $\mathrm{RC}_{7}$ & 377 & 0.26 \\
\hline $\mathrm{RC}_{4}$ & 472 & 0.04 \\
\hline
\end{tabular}

Table 5

The KPI matrix

\begin{tabular}{|l|c|c|c|c|c|}
\hline \multirow{2}{*}{$\begin{array}{c}\text { Key } \\
\text { indicator }\end{array}$} & \multirow{2}{*}{$\begin{array}{c}\text { Specific } \\
\text { weight }\left(P_{i}\right)\end{array}$} & \multicolumn{3}{c|}{ Factors for KPI } & \multirow{2}{*}{ KPIi, } \\
\cline { 3 - 5 } & Norm & Target & Fact & \\
\hline $\mathrm{K} 1$ & 0.8 & 320 & 300 & 377 & 85 \\
\hline $\mathrm{K} 2$ & 0.1 & 2.5 & 0 & 2 & 125 \\
\hline $\mathrm{K} 3$ & 0.05 & 4 & 0 & 4 & 100 \\
\hline $\mathrm{K} 4$ & 0.05 & 2 & 0 & 2 & 100 \\
\hline \multicolumn{7}{|l|}{ Coefficient of effectiveness $\left(\sum\left(\mathrm{KPI}_{i} \cdot P_{i}\right)\right.$} & \\
\hline
\end{tabular}

For example, Table 5 presents the results of calculating the performance coefficient for $\mathrm{RC}_{7}$, where the first key indicator $(K 1)$ is the SAIDI.

Other indicators are also used in the KPI matrix. For example, in Table 5 (KPI matrix for calculating the efficiency coefficient of the RC subdivisions for the power distribution), the key indicators are given: $K_{l}-$ the mean SAIDI, min. (from the database from the RC subdivisions for reporting by No. 11-NCRPMS form); $K_{2}$ - the percentage of services in the list of guaranteed standards, the execution time of which exceeded the established time limits, for example, the service delivery of distribution point passport by Distribution system operator within 10 business days from the date of receiving the corresponding request of the consumer, \% (the database from the RC subdivisions for reporting by No.12-NCRPMS - distribution form); $K_{3}$ - the number of VQ complaints found to be reasonable from the database from the $\mathrm{RC}$ subdivisions for reporting by No.14-NCRPMS form, pcs.; $K_{4}-$ the number of VQ complaints that remained unresolved at the end of the reporting year from the database of the RC subdivisions for reporting by No.14-NCRPMS form, pcs.

The aim for $K_{1}$ is the target indicators of the power supply quality for the urban (rural) territory. They are set by the Regulator (according to [11] for urban areas -150 minutes, for rural areas -300 minutes). The RC should achieve target indicators in the course of 8 years of stimulating regulation action.

The norm for $K_{1}$ is the targets that are calculated for each year and are approved by the NCRPMS regulations for each $\mathrm{RC}$ (taking into account the average actual values of the SAIDI of this $\mathrm{RC}$ for the last three reporting years).

Key indicators $K_{2}, K_{3}, K_{4}$ should aim to 0 , and the norm can be determined in the RC based on actual data and longterm aims.

A conditional example is considered, since the number of key performance indicators is usually much higher and takes into account not only the indicators relating to the reliability of power supply and VQ.

Consider an example of the proposed motivation mathematical model for improving the quality of power supply. We get by $\mathrm{f}(1)$ for $\mathrm{PC}_{7}$ according to Tables 3-5:

- in case of acceptance of the hypothesis that an RC subdivision is the factor influencing the SAIDI (as a result of the one-way ANOVA)

$$
A B_{7}=0.1 \cdot B \cdot \frac{90}{100}=0.09 \cdot B,
$$

that is, the annual prize of the management staff of REM7 (director, deputy director and chief engineer) will be $9 \%$ of the basic salary;

- in case of not accepting the hypothesis that an RC subdivision is the factor influencing the SAIDI (as a result of the one-way ANOVA)

$$
A B_{7}=0.26 \cdot B \cdot \frac{90}{100}=0.234 \cdot B,
$$

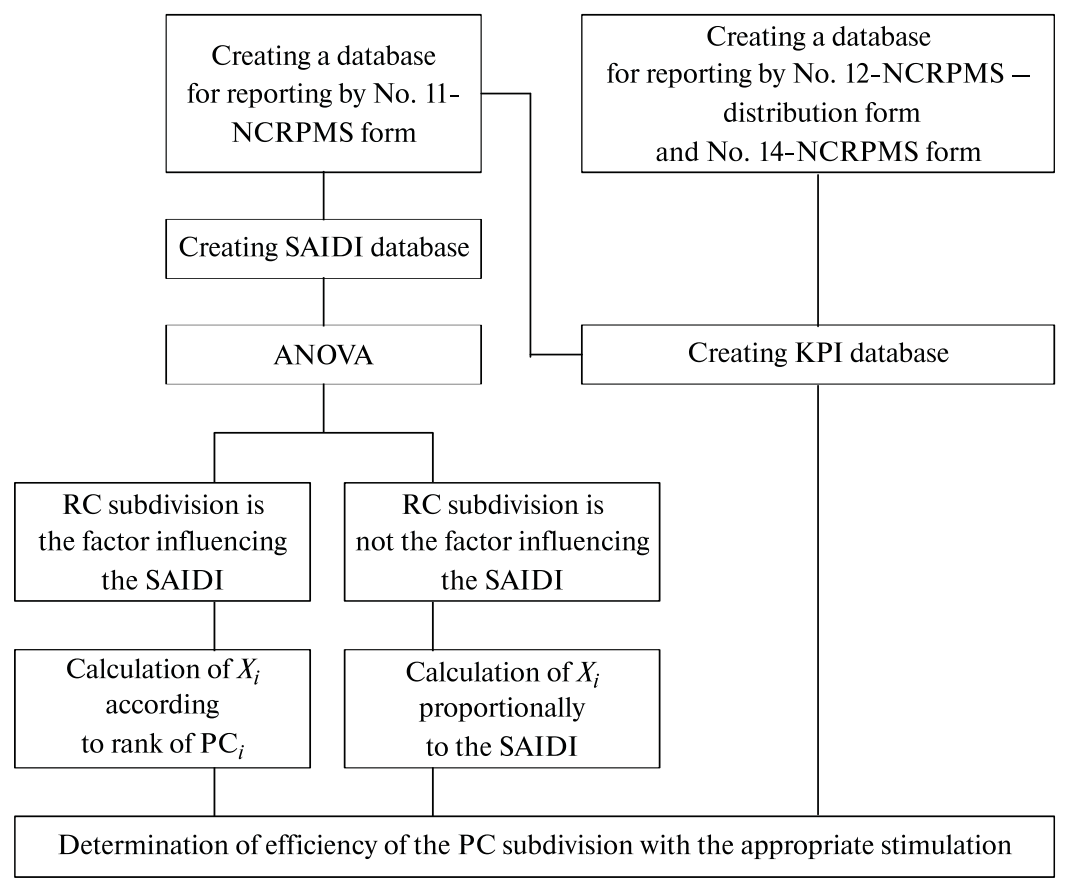

Fig. A scheme of stimulating PC subdivisions for the distribution of electricity energy for improvement of the power supply quality 
that is, the annual prize of the management staff of REM7 (director, deputy director and chief engineer) will be $23.4 \%$ of the basic salary.

As you can see, the practical application of the proposed motivation mathematical model can stimulate the PC to improve the quality of power supply. At the same time, if a subdivision of the PC is an influential factor for the quality of power supply, then the stimulation is more significant.

The proposed motivational mathematical model based on the one-way dispersion analysis is used in the improved scheme of stimulating of PC subdivisions for the distribution of electricity energy to improvement of the quality of power supply, is shown in Figure, where the ANOVA is an abbreviation created by the words Analysis Of Variance (dispersion analysis).

Data of reporting forms of PC subdivisions can be used as key indicators in the scheme of stimulation of RC subdivisions for distribution of power energy to improve the power supply quality (as one of the components of achieving the best performance), for example:

No. 11-NCRPMS form (reliability indices: SAIDI, SAIFI, ENS etc.; completeness index, correctness index and accuracy index of reporting data);

- No. 12-NCRPMS-distribution form (percentage of services in the list of guaranteed standards, the execution time of which exceeded the established time; index of completeness of registration of services, etc.);

- No. 14-NCRPMS form (the number of complaints about VQ, acknowledged to be justified, pcs, the number of complaints about VQ, remaining unsolved at the end of the reporting year, etc.).

In order to achieve the strategic aim of improving the quality of power supply, in the RC for the transmission of electricity energy, the following key indicators that are included in the database for completing of No. 13-NCRPMS form can be used:

- ENS (Energy Not Supplied for users of the transmission system);

- AIT (Average Interruption Time).

In turn, the RC for the supply of power energy can use as a key indicator of the effectiveness of subdivisions performance indicators included in the database to fill No. 12-NCRPMSsupply form of reporting, in particular, the percentage of services in the list of guaranteed standards, the execution time of which exceeded the established time frame.

Conclusions.

1. The motivational mathematical model for improving the power supply quality is perfected by generalizing and clarifying the formulas to determine the incentive factor for achieving the best performance of the RC subdivisions for distribution of power supply $X_{r}$ by subdivision rating (in case of acceptance of the hypothesis that an RC subdivision is the factor influencing the SAIDI as a result of the one-way ANOVA).

2. The list of key indicators for the annual evaluation of the specialist's activity results in subdivisions of RC for distribution of power energy renewed taking into account the requirements of the latest regulatory documents.

3 . The proposed motivational mathematical model for improving the power supply quality can be used in the incentive scheme for achievement of the best performance of the PC subdivisions for the power energy distribution in full or in part.

Only results of the one-way ANOVA of database can be used to determine the incentive factor for achieving the best performance of the RC subdivisions for distribution of power supply $X_{i}$. Or only the SAIDI can be used as KPI without application of the ANOVA.

4. The improved incentive scheme on the basis of the given mathematical model for maintaining or improving power supply quality can be realized both in the accessible interface, for example, Microsoft Excel, and in the automated control system of the distributive company.

5. The list of key indicators for the annual evaluation of the specialist's activity results in subdivisions of RC for transmis- sion and supply of electricity energy is determined, which will contribute to the achievement of the strategic aim of improving the quality of power supply.

The ANOVA can be used to determine the RC subdivisions for the electrical energy transmission or power supply which influence the indicators of power supply quality.

\section{References.}

1. CEER (2012). $5^{\text {th }}$ CEER Benchmarking Report on the Quality of Electricity Supply - 2011. Retrieved from https://www.ceer. eu/documents/104400/-/-/0f8a1aca-9139-9bd4-e1f5-cdbdf10c4609.

2. CEER (2019). $6^{\text {th }}$ CEER Benchmarking Report on the Quality of Electricity and Gas Supply - 2016. Retrieved from https:// www.ceer.eu/documents/104400/-/-/d064733a-9614-e320a068-2086ed27be7f.

3. Tymchuk, S., \& Miroshnyk, O. (2015). Assess electricity quality by means of fuzzy generalized index. Easternt-European Journal of enterprise technologies, 3/4(75), 26-31. https:// doi.org/10.15587/1729-4061.2015.42484.

4. Legislation of Ukraine (2019). Law of Ukraine "On the Electricity Market” (No. 2019-19 of April 13, 2017). The Verkhovna Rada of Ukraine. Retrieved from http://zakon2.rada.gov.ua/ laws/show/2019-19/page.

5. Legislation of Ukraine (2018). NCRPMS Resolution dated June 12, 2018, No. 375 "On Approval of the Procedure for Provision of Quality Standards for Power Supply and Compensation to Consumers for Non-Compliance". The Verkhovna Rada of Ukraine. Retrieved from https://zakon.rada.gov.ua/laws/ show/v0375874-18.

6. Bertling, L., Allan, R., \& Eriksson, R. (2005). A ReliabilityCentered Asset Maintenance Method for Assessing the Impact of Maintenance in Power Distribution Systems. IEEE Trans. Power Syst., 20(1), 75-82. https://doi.org/10.1109/TPWRS.2004.840433.

7. Komada, P., Trunova, I., Miroshnyk, O., Savchenko, O., \& Shchur, T. (2019). The incentive scheme for maintaining or improving power supply quality. PRZEGLĄD ELEKTROTECHNICZNY, 5, 79-82. https://doi.org/10.15199/48.2019.05.20.

8. Legislation of Ukraine (2018). NCRPMS Resolution dated December 12, 2018, No. 374 "On Approval of Forms of Reporting Regarding Power Supply Quality Indicators and Instructions for their Filing”. The Verkhovna Rada of Ukraine. Retrieved from http://zakon.rada.gov.ua/laws/show/ v0374874-18.

9. Diez, David M., Barr, Christopher D., \& Cetinkaya-Rundel, Mine (2017). OpenIntro Statistics (3rd ed.). OpenIntro. ISBN-13: 978-1943450039, ISBN-10: 194345003X.

10. Methodical instructions for the accounting and analysis in the power systems of the technical state of distribution networks with voltage 0.38-20 kV with transmission air linesr: SOU-H MPE 40.1.20.576:2005. Retrieved from http://mpe.kmu.gov.ua/ minugol/control/publish/article?art_id=245088195.

11. Legislation of Ukraine (2013). NCRPMS Resolution dated July 23, 2013 p. No. 1009 "On the establishment of regulatory parameters with a long-term validity, for the purposes of stimulating regulation”. The Verkhovna Rada of Ukraine. Retrieved from http://zakon0.rada.gov.ua/laws/show/z1266-13.

12. Kholiddinov, I. (2016). Electric Power Quality Analysis 6-10/0.4 kV Distribution Networks. Energy and Power Engineering, 8(6). https://doi.org/10.4236/epe.2016.86025.

\section{Удосконалення мотиваційної моделі покращення якості електропостачання з використанням однофакторного дисперсійного аналізу}

\author{
І. М. Трунова, О. О. Мірошник, О.А. Савченко, \\ О.М. Мороз
}


Харківський національний технічний університет сільського господарства імені Петра Василенка, м. Харків, Україна, e-mail: omiroshnyk@ukr.net

Мета. Удосконалення мотиваційної математичної моделі покращення якості електропостачання з використанням однофакторного дисперсійного аналізу для реалізації в системі автоматизованого керування регульованою компанією з розподілу електричної енергії.

Методика. Використовується однофакторний дисперсійний аналіз бази даних індексів SAIDI зі звітів підрозділів регульованої компанії з розподілу електричної енергії для оцінювання значимості впливу цих підрозділів на безперервність електропостачання.

Результати. Отримані узагальнені та уточнені розрахункові співвідношення, що дозволяють визначити коефіцієнт стимулювання досягнення кращих результатів діяльності із забезпечення безперервності електропостачання підрозділами регульованої компанії з розподілу електричної енергії. Удосконалена схема стимулювання цих підрозділів до покращення якості електропостачання. Визначені ключові показники якості електропостачання для щорічної оцінки результатів діяльності підрозділів регульованих компаній з передачі й постачання електричної енергії.

Наукова новизна. Удосконалена мотиваційна математична модель покращення якості електропостачання шляхом узагальнення та уточнення виразів для визначення коефіцієнту стимулювання досягнення кращих результатів діяльності підрозділом регульованої компанії.

Практична значимість. Удосконалення мотиваційної математичної моделі покращення якості електропостачання дозволить ефективніше використовувати ії в автоматизованій системі керування регульованою компанією з розподілу електричної енергії.

Ключові слова: однофакторний дисперсійний аналіз, мотиваційна математична модель, якість, електропостачання

\section{Усовершенствование мотивационной модели улучшения качества электроснабжения с использованием однофакторного дисперсионного анализа}

\author{
И. М. Трунова, А.А. Мирошник, А.А. Савченко, \\ А. Н. Мороз
}

Харьковский национальний технический университет сельского хозяйства имени Петра Василенко, г. Харков, Украина, e-mail: omiroshnyk@ukr.net

Цель. Усовершенствование мотивационной математической модели улучшения качества электроснабжения с использованием однофакторного дисперсионного анализа для реализации в системе автоматизированного управления регулируемой компании по распределению электрической энергии.

Методика. Используется однофакторный дисперсионный анализ базы данных индексов SAIDI из отчетов подразделений регулируемой компании по распределению электрической энергии для оценки значимости влияния этих подразделений на непрерывность электроснабжения.

Результаты. Получены обобщенные и уточненные расчетные соотношения, которые позволяют определять коэффициент стимулирования достижения лучших результатов деятельности по обеспечению беспрерывности электроснабжения подразделениями регулируемой компании по распределению электрической энергии. Усовершенствована схема стимулирования этих подразделений к улучшению качества электроснабжения. Определены ключевые показатели качества электроснабжения для ежегодной оценки результатов деятельности подразделений регулируемых компаний по передаче и поставке электрической энергии.

Научная новизна. Усовершенствована математическая модель улучшения качества электроснабжения путем обобщения и уточнения формул для определения коэффициента стимулирования достижения лучших результатов деятельности подразделения регулируемой компании.

Практическая значимость. Усовершенствование мотивационной модели улучшения качества электроснабжения позволит эффективнее использовать её в автоматизированной системе управления регулируемой компанией по распределению электрической энергии

Ключевые слова: однофакторный дисперсионный анализ, мотивационная математическая модель, качество электроснабжение

Recommended for publication by S. Yu. Shevchenko, Doctor of Technical Sciences. The manuscript was submitted 18.10.18. 